\title{
The Relationship Between Financial Connections and Business Performance of Private Enterprises: Evidence from Chinese Listed Firms
}

\author{
Zhuwei Li", Sennan Liu, Shunyao Wang, Baolu Wang \\ Faculty of Management and Economics, Dalian University of Technology, Dalian, China \\ Email address: \\ 54awu@163.com (Zhuwei Li) \\ ${ }^{*}$ Corresponding author
}

\section{To cite this article:}

Zhuwei Li, Sennan Liu, Shunyao Wang, Baolu Wang. The Relationship Between Financial Connections and Business Performance of Private Enterprises: Evidence from Chinese Listed Firms. International Journal of Economics, Finance and Management Sciences.

Vol. 7, No. 1, 2019, pp. 29-36. doi: 10.11648/j.ijefm.20190701.16

Received: January 10, 2019; Accepted: March 12, 2019; Published: March 29, 2019

\begin{abstract}
Sample data were acquired from Chinese listed private enterprises. Then, the random effect model of panel data was used to establish a regression model of business performance and firm financial connection and examine the relationship between them. Results showed that the higher the degree of private enterprise financial connection, the worse the business performance of the enterprise. In other words, financial connection provides financing convenience, but it cannot improve business efficiency. We also classified the sample enterprises according to size and found that financial connection has a greater negative impact on the performance of small-scale firms compared with large-scale ones. Moreover, dividing the sample enterprises according to the degree of financial marketization in the location of the sample enterprises indicated that financial connection has a negative effect on the performance of private enterprises in areas with low degree of financial marketization. The classification of financial connection also revealed that non-bank financial connection exerts a greater negative impact on corporate performance than bank financial connection.
\end{abstract}

Keywords: Financial Connection, Business Performance, Private Enterprise, Panel Data

\section{Introduction}

An open financing channel is an important factor in promoting the growth and development of private enterprises. During this period of economic transition in China, the financial system and laws remain flawed, hence the enterprises in china mostly develop financial and political relationships to compensate for the inefficient general financing and corporate governance mechanisms. Cull found that the increase in foreign aid financing can significantly increase the reinvestment ratio of private enterprises in China [1]. Establishing connections between enterprises and financial institutions can be achieved in two ways: by cross shareholding (direct method) and by hiring senior executives with financial background (indirect method) ${ }^{1}$. However, cross

1 The senior executives include general manager, vice general manager, chief financial officer, directors and supervisors Executives with financial background shareholding for private enterprises is not easily achieved in China; thus, most companies prefer to employ persons with financial background as company executives to achieve financing channels.

The phenomenon that enterprises employ the executives with financial background is defined as financial connection which can be measured by the ratio of financial affiliate executives to the total number of executives. It is a critical component of the relationship and reputation mechanism, which, in turn, has a significant influence on business activities and outcomes. On one hand, financial connection can improve the performance of private enterprises to a certain extent. Companies employ persons with a financial background as executives so that enterprises and financial institutions can form close relationship networks, provide

refer to those who have the experience of working in banks, securities firms, insurance companies, trust companies and funds. The resumes of executives can be acquired publicly from the WIND database. 
recessive guarantee for the company and help boost the company reputation. Such efforts can thus relieve the financing constraints of private enterprises. In addition, hiring such individuals can aid enterprises in optimising financing schemes and improving their capital operation capacity. On the other hand, financial connection can also restrain the performance of private enterprises. Companies who hire a person with a background in financial institutions must pay substantial costs, including high wages and expenditure for search, negotiation, time and rent-seeking endeavours. Moreover, upon establishing financial connections, enterprise management may locate a low-cost financing channel, but because the connection has been established with a particular institution, the enterprise is expected to encounter difficulty in accessing new low-cost financing channels.

Thus, how can an investigation of the financial connections of Chinese private enterprises be conducted? Can financial connections improve the performance of private enterprises? These problems are of considerable theoretical and practical significance for the study of financial development and economic transformation in China.

Accordingly, this research listed the relevant data of private enterprises in China from 2014 to 2018 as the research sample. A panel data random effect model was utilised to study the relationship between enterprise performance and financial connections. The contribution of this paper relative to the existing literature lies in several aspects. First, the extant research on reputation and credit examine political relation, whereas this work takes financial connection into account. Second, prior research focuses on the relationship of enterprises in addressing the problem of financing constraints, whereas this research further studies the influence of financial connection on the operation performance of private enterprises and analyses the regional financial development, enterprise scale and heterogeneity of financial connection types. Third, the current literature emphasises banks' financial connections whilst this work considers the impact of non-bank financial connections on corporate performance. Fourth, present studies mainly take developed economies as their research objects. By contrast, using the economic transformation in China as the research object, this paper provides references for the operation mechanism of China during its economic transition.

The remainder of this paper is divided into four parts. The next chapter reviews existing literature on operation performance of private enterprises and the impact of financial connection on enterprises. The third chapter discusses Sample data and research methods. The fourth chapter presents the empirical analysis and results. The last chapter is the conclusion and suggestion.

\section{Literature Review}

\subsection{Operation Performance of Private Enterprises}

The literature on the operating performance of private enterprises chiefly focuses on the factors influencing the development of private enterprises, including enterprise scale, research and development (R\&D), ownership concentration and the level of regional financial development. Jovanovich et al. found that, compared with the small-scale enterprises, large enterprises tend to have better business and political capabilities, coupled with good reputation and assets that can be mortgaged to bring credit, rendering them more likely to achieve long-term development [2]. Fung posited a relatively close relationship between $R \& D$ investment and stock prices, in which the influence of R\&D input on the enterprise's future output is uncertain, thus increasing stock price volatility [3]. Francis et al. examine how political connections impact the process of going public [4]. Based on the experience of the newly public firms from Chinese security markets and using multiple measures of political connections, they found robust evidence that the issuing firms with political connections reap significant preferential benefits in the process of going public.

Rajeev shows that smaller firms exhibit a higher profit rate, lower survival probability and difficulty in accessing the capital market. Small firms are significantly more productive and they would rather employ the executives with financial background to solve financing constraints [5]. Similarly, Rajan and Zingales point out that financial development reduces the costs of external finance to firms [6]. Industrial sectors that are relatively more in need of external finance develop disproportionately faster in countries with more-developed financial markets. Enterprises in the area with low-financial development level are faced with larger financing constraints and have the same desire to deal with it. Salim and Yadav indicate that firm performance, which is measured by return on asset (ROA), return on Equity (ROE) have negative relationship with all types of debt [7]. Vu et al. found that number of members in the board and the ownership concentration influence positively ROA, but do not have any impact on ROE [8].

\subsection{Impact of Financial Connection on Enterprises}

Some scholars believe that financial connection has a positive effect on enterprise development. Jiang et al. proposed that finance-related enterprise groups have a higher debt ratio and that another reason why the enterprise maintains relationships is to obtain timely and effective assistance in the event of an economic morass [9]. Blau et al. studied companies that received financial support from the troubled asset relief programme (TARP) during the US Financial Crisis of 2008. They found that by lobbying for a connected company, a firm is not only more likely to be affected by the TARP funds but could also gain a greater amount of government funding than an unrelated company [10]. Huang et al. found that investment bankers in corporate boards are significantly positively correlated with the probability of mergers and acquisitions [11].

Other scholars argue that financial connection exerts a negative effect on enterprise development. Luo et al. show that bank holdings increase corporate debt financing but reduce corporate value using Chinese data [12]. Higgins found banks acting as a conflict of interest in the control market [13]. 
Chia-chung Chan suggests that multiple-bank relationship can drive firms to take higher risks under information asymmetry between banks and firms [14].

Burak et al. found that finance experts significantly affect the finance and investment policies of firms on whose board they serve. Commercial bankers reduce the sensitivity of investment to cash flow by extending large loans, while investment bankers are associated with larger debt issues and worse acquisitions [15]. Kang and Kim point out that the CEO incentives are significantly affected by commercial banker directors' conflicts of interest and when affiliated banker directors are members of the compensation committee or its chair, they seem to reduce the convexity of CEO compensation [16].

Given the variation in their subjects, the existing studies predominantly emphasise political relations (See Houston and Leonard) [17-18], whereas research on financial relation mostly focuses on the influence of banking financial connection on the business development of enterprises. Moreover, most of the literature highlights the relationship between enterprises and its role in solving the problem of corporate financing constraints. Therefore, based on extant research, the current work takes non-bank financial connection into account. In the study of the influence of financial linkages on the operating performance of private enterprises, this work analyses the impacts of the regional

$$
R O A_{i t}=a_{i t}+\beta_{1} F I N_{i t}+\beta_{2} N S W_{i t}+\beta_{3} F D_{i t}+\beta_{4} R D_{i t}+\beta_{5} F O C U S_{i t}+\sum_{j=1}^{5} \beta_{5+j} Y E A R_{i j}+\sum_{j=1}^{20} \beta_{10+j} I N D_{i j}+\varepsilon_{i t}
$$

Among the variables, $R O A$ indicates the asset yield of the enterprise (an explained variable) whereas $F I N$ represents the financial connection strength of the enterprise (the core explanatory variable). Financial connection is divided into two types: bank connection and non-bank relationship. Banking financial connection (FIN1) refers to the proportion of executives with previous or current employment in the bank. Non-bank financial connection (FIN2) constitutes a proportion of the total number of executives with previous or present employment in other financial institutions, such as financial development, enterprise scale, and the types of financial connection on the relationship between financial connection and business performance. Eventually, we draw the conclusions and propose corresponding suggestions.

\section{Sample Data and Research Methods}

\subsection{Sample Selection and Data Source}

Private enterprises listed from 2014-2018 constitute the research sample. Data from a total of 189 private enterprises were collected after excluding 1) enterprises that were listed in the shell and the information disclosure of financial data, and 2) those that had vacancies for several years. Financial data were obtained from the annual report of the listed company and from the WIND database.

\subsection{Index Selection and Model Construction}

The relationship between the financial connections and operation performance of private enterprises is examined using a multivariate regression model. Following the model proposed by Cebeci which weighs and ranks main indicators affecting the R\&D performance, we changed the model indicators to make it compliant with Chinese company data [19].

securities companies, insurance companies and trust companies. In addition, we controlled the other variables that may affect business performance, namely, enterprise scale $(N S W)$, the level of financial development $(F D)$, enterprise R\&D $(R D)$, equity concentration (FOCUS), industry variables $(I N D)$ and annual variables $(Y E A R)$. In addition, $\varepsilon_{i}$ is the error term and $\beta$ is an estimation parameter. Here, the sign and significance of $\beta_{1}$ signify the main research points. The main index definitions are shown in Table 1.

Table 1. Definitions of the Main Indicators.

\begin{tabular}{ll}
\hline Variables & Definition \\
\hline ROA & Return on assets, as the net income divided by average total assets \\
$F I N$ & Ratio of financial affiliate executives to the total number of executives \\
$N S W$ & Natural log of the main business income of the company \\
$F D$ & Level of financial development measured by the 'year-end loan balance/gross regional product' of each province \\
$R D$ & Enterprise R \& D investment intensity expressed as the ratio of enterprise R\&D investment to total assets \\
$F O C U S$ & Ratio of the number of shareholders to the total number of shares \\
$I N D$ & Virtual variables of the industry divided according to the virtual variables in the industry classification guidance of listed companies \\
$Y E A R$ & published by the CSRC in 2012 \\
\hline
\end{tabular}

\subsection{Descriptive Statistics of Variables}

Table 2 presents the descriptive variables and the results. As shown in Table 2, the mean of the operating performance $(R O A)$ is 7.591 , indicating that the operating performance of private enterprises is generally in surplus. The average value of financial connection $(F I N)$ is 0.066 . In other words, the private enterprise financial connection intensity is $6.6 \%$. Considering that the average number of executives of private enterprises listed above is in excess of 19, this means each enterprise above has at least one executive with financial background on average on the whole. The maximum of FIN 
has even reached up to 0.507 . The average FIN suggests that 1$)$ executives with financial background occupy a significant proportion in the enterprise management, and 2) the enterprises prefer executives with such background. The result of Table 2 also reveals that financial connection has become non-negligible for private enterprises, thus research on the relationship between financial connection and operating performance is urgent and has practical significance.

Table 2. Descriptive Statistics of Variables.

\begin{tabular}{|c|c|c|c|c|c|}
\hline Variables & Number of samples & Mean & Standard deviation & Minimum & Maximum \\
\hline$R O A$ & 935 & 7.591 & 6.312 & -36.765 & 62.114 \\
\hline$F I N$ & 935 & 0.066 & 0.081 & 0.000 & 0.507 \\
\hline$N S W$ & 935 & 18.194 & 0.798 & 17.819 & 22.793 \\
\hline$F D$ & 935 & 1.312 & 0.524 & 0.000 & 2.331 \\
\hline$R D$ & 935 & 0.023 & 0.032 & 0.000 & 0.159 \\
\hline FOCUS & 935 & 33.291 & 14.091 & 4.751 & 89.750 \\
\hline
\end{tabular}

\section{Empirical Analysis}

\subsection{Correlation Test}

Table 3 lists the connection test results of the variables. As shown in Table 3, financial connection strength $(F I N)$ and enterprise operating performance $(R O A)$ have a negative connection significant at the $5 \%$ level. In addition, regional financial development level $(F D)$ is significantly correlated with enterprise scale (NSW), enterprise R\&D investment $(R D)$ and equity concentration (FOCUS), indicating that a mutual influence exists between the control variables. No significant relationship is found between several control variables. Financial strength $(F I N)$ is associated with enterprise scale $(N S W)$, level of regional financial development $(F D)$, enterprise $\mathrm{R} \& \mathrm{D}(R D)$ and enterprise ownership concentration (FOCUS). Such relationships demonstrate that the basic model of the multicollinearity problem is not present.

Table 3. Correlation Test between Variables.

\begin{tabular}{|c|c|c|c|c|c|c|}
\hline & $R O A$ & $F I N$ & $N S W$ & $F D$ & $R D$ & FOCUS \\
\hline$R O A$ & 1.0000 & & & & & \\
\hline FIN & $-0.0412 * *$ & 1.0000 & & & & \\
\hline$N S W$ & $0.1146^{* * *}$ & -0.0461 & 1.0000 & & & \\
\hline$F D$ & $0.0611 *$ & -0.0070 & $0.1322 * * *$ & 1.0000 & & \\
\hline$R D$ & $0.0109 *$ & 0.0210 & 0.0012 & $0.1019 * * *$ & 1.0000 & \\
\hline FOCUS & -0.0575 & 0.0119 & 0.0306 & $-0.0769 *$ & $-0.1012 * * *$ & 1.0000 \\
\hline
\end{tabular}

Note: $* * *, * *$ and $*$ are marked at the significance level of $1 \%, 5 \%$, and $10 \%$, respectively.

Furthermore, different degrees of connection with enterprise business performance $(R O A)$ are associated with $F I N, N S W, F D, R D$ and FOCUS. Among the variables, NSW, $F D$ and $R D$ are positively correlated with $R O A$. By contrast, FOCUS is negatively correlated with ROA, and the absolute value of the coefficient is minimal, which is consistent with the results below.

\subsection{Regression Test}

The Hausman test which is used to differentiate between fixed effects model and random effects model in panel data was first conducted before returning to the model. Results show that the value of probability (P-value) is larger than the marked significant level of $10 \%$. Hence, the original hypothesis was accepted, and the random effect model was used. One control variable was introduced at a time in order to test the relationship between the core variable financial connection $(F I N)$ and business performance $(R O A)$, under the condition of controlling of the virtual variables industry $(I N D)$ and year (YEAR). Regression results are presented in Table 4.

Table 4. Regression Results: ROA and FIN.

\begin{tabular}{llllll}
\hline \multirow{2}{*}{ Variables } & ROA & & & & \\
\cline { 2 - 5 } & Model 1 & Model 2 & Model 3 & Model 4 & Model 5 \\
\hline \multirow{2}{*}{$F I N$} & $-4.779^{* *}$ & $-4.732^{* *}$ & $-4.635^{* *}$ & $-4.667^{* *}$ & $-4.769^{* *}$ \\
& $(2.306)$ & $(2.297)$ & $(2.307)$ & $(2.306)$ & $(2.317)$ \\
NSW & & $0.801^{* * *}$ & $0.796^{* * *}$ & $0.798^{* * *}$ & $0.823^{* * *}$ \\
& & $(0.219)$ & $(0.220)$ & $(0.218)$ & $(0.219)$ \\
$F D$ & & 0.308 & 0.257 & 0.237 \\
& & $(0.362)$ & $(0.364)$ & $(0.367)$ \\
RD & & & 7.704 & 7.641 \\
$F O C U S$ & & & $(7.614)$ & $(7.615)$ \\
IND & & & & -0.0121 \\
YEAR & & & YES & $(0.014)$ \\
\end{tabular}




\begin{tabular}{llllll}
\hline \multirow{2}{*}{ Variables } & ROA & Model 2 & Model 3 & Model 4 & Model 5 \\
\cline { 2 - 6 } & Model 1 & $-8.787^{*}$ & $-9.217^{* *}$ & $-9.301^{* *}$ & $-9.328^{* *}$ \\
Constant term & $6.986^{* * *}$ & $(4.560)$ & $(4.577)$ & $(4.552)$ & $(4.567)$ \\
Observations & $(2.982)$ & 935 & 926 & 926 & 925 \\
Wald & 935 & 311.09 & 301.36 & 302.51 & 302.25 \\
$R^{2}$ & 285.17 & 0.2289 & 0.2367 & 0.2388 & 0.2392 \\
\hline
\end{tabular}

Note: The value of $\mathrm{t}$ is in brackets and all regression controls the annual and industrial variables.

Note: $* * *, * *$ and $*$ are marked at the significance level of $1 \%, 5 \%$, and $10 \%$, respectively.

Column 1 in Table 4 shows that financial connection (FIN) has a direct return to business performance $(R O A)$. The finance-related coefficient is significantly negative under the $5 \%$ level, hence financial connection reduces the return on assets of the enterprise. Column 2 depicts the financial connection returns to the business performance after adding enterprise scale $(N S W)$ as the control variable. Column 3 incorporates regional financial development level $(F D)$ as the control variable. Considering the positive contributions of $R \& D$ input to enterprise growth and the important influence of ownership concentration on the decision making and resource allocation of firms, Columns 4 and 5 include enterprise R\&D $(R D)$ and equity concentration (FOCUS) as control variables, respectively. At this point, all control variables are added in Model 5.

The findings reveal that the FIN coefficient is significantly negative at the $5 \%$ level for all models, indicating that financial connection has a significant negative effect on the operation performance of private enterprises. Meanwhile, the $N S W$ coefficient is always positive at the $1 \%$ level, which signifies that the enterprise scale exerts a significant positive effect on enterprise operation performance. The coefficient of $F D$ and $R D$ is a positive value that fluctuates within a reasonable range, suggesting that it has a positive promoting effect on firm performance, although such an effect is not statistically significant. The FOCUS coefficient is negative, which is consistent with extant research results, implying that the increase of ownership concentration can lead to deviation in enterprise decision making and resource allocation as well as adversely affect the performance of enterprises.

The regression results in Table 4 are surprising because it is contrary to general perception that financial connections can help enterprises improve performance. By establishing financial connections, enterprises expect to acquire more rare resources, get credit guarantee and ease financial constraints to promote the increase of business performance. However, building and maintaining financial connections will bring extra costs, including tangible costs and intangible costs. Tangible costs are reflected in the human cost and expenditure. Nevertheless, intangible expenditure tends to be neglected. It is reflected in the waste of executives' energy for seeking financial connections, worries about illegal bribery and potential risk. Most enterprises can realize tangible costs resulted from financial connections and expect that the benefits of establishing financial connections can make up for the loss caused by it, however, intangible costs are often neglected. Only when tangible costs and intangible costs are summed can the total costs be described accurately and it is likely that the total costs are in excess of the benefits from financial connections. Hence, financial connections have a negative influence on the business performance of enterprises on the whole.

\subsection{Further Test}

Existing studies show that large and small enterprises experience varying degrees of difficulty in obtaining government support and resources. In addition, companies in more developed areas enjoy relatively transparent processes and services. Economic relationships between enterprises in less developed areas may need to adapt to the local development. Therefore, this work classified the total samples into small-scale and large-scale enterprises, with four sub-samples of high financial development and low financial development, respectively. Regression results are shown in Table 5.

Table 5. Regression Results of Sub-Sample (1).

\begin{tabular}{lllll}
\hline \multirow{2}{*}{ Variables } & $\boldsymbol{R O A}$ & Large-scale & Low-financial development level & High-financial development level \\
\cline { 2 - 5 } & Small-scale & -2.236 & $-5.273^{*}$ & -4.101 \\
\multirow{2}{*}{$F I N$} & $-5.952^{*}$ & $(3.332)$ & $(3.152)$ & $(3.217)$ \\
& $(3.109)$ & $0.713^{* *}$ & $1.001^{* * *}$ & $0.633^{*}$ \\
\multirow{2}{*}{ NSW } & $0.675^{*}$ & $(0.296)$ & $(0.312)$ & $(0.308)$ \\
& $(0.349)$ & 0.451 & 0.406 & 0.248 \\
$F D$ & 0.179 & $(0.523)$ & $(0.533)$ & $(0.501)$ \\
& $(0.446)$ & -1.113 & 6.457 & 5.084 \\
RD & 12.221 & $(12.071)$ & $(11.436)$ & $(11.339)$ \\
FOCUS & $(10.412)$ & 0.0135 & -0.0138 & -0.0168 \\
\multirow{2}{*}{$I N D$} & $-0.0610^{* *}$ & $(0.017)$ & $(0.019)$ & $(0.020)$ \\
$Y E A R$ & $(0.031)$ & YES & YES & YES \\
\hline
\end{tabular}




\begin{tabular}{lllll}
\hline \multirow{2}{*}{ Variables } & $\boldsymbol{R O A}$ & & & \\
\cline { 2 - 5 } & Small-scale & Large-scale & Low-financial development level & High-financial development level \\
\hline \multirow{2}{*}{ Constant term } & -4.886 & -6.698 & $-14.71^{* *}$ & -3.615 \\
\multirow{2}{*}{ Observations } & $(7.093)$ & $(6.560)$ & $(6.174)$ & $(6.988)$ \\
Wald & 455 & 454 & 458 & 447 \\
$R^{2}$ & 165.562 & 144.099 & 179.413 & 133.333 \\
\hline
\end{tabular}

Note: The value of $\mathrm{t}$ is in brackets and all regression controls the annual and industrial variables.

Note: $* * *, * *$ and $*$ are marked at the significance level of $1 \%, 5 \%$, and $10 \%$, respectively.

Table 5 demonstrates that the negative impact of financial connections on the performance of small scale enterprises is even more significant. Small enterprises lack collateral and experience a more severe information asymmetry problem. Thus, their difficulties pertaining to financing constraints are more pronounced. Therefore, small-scale private enterprises tend to establish a link between financial or political connection and other informal institutions to effectively alleviate their financing constraints. At the same time, compared with the costs for large enterprises, the cost for small enterprises to establish and maintain financial connection would account for a much higher percentage of business performance. Hence, the positive influence of financial connections to improve the financing constraints of small enterprise is insufficient to offset the negative impact of the financial connection. The findings demonstrate that the financial connection coefficient is not significant in the region with high financial development. By contrast, the financial connection coefficient is significantly negative for an area with low financial development, implying that, in such areas, greater reliance on financial related business.

The current research further examines whether the influence of financial connection on the performance of private enterprises significantly differs due to the varied types of financial connections. Financial connection is divided into two categories: banking financial connection (FINI) and non-bank financial connection (FIN2), and two corresponding sub-samples are returned. The results are shown in Table 6.

Table 6. Regression Results of Sub-Sample (2).

\begin{tabular}{lll}
\hline \multirow{2}{*}{ Variables } & $\boldsymbol{R O A}$ & \\
\cline { 2 - 3 } & $\boldsymbol{F I N 1}$ & $\boldsymbol{F I N 2}$ \\
\hline \multirow{2}{*}{ FIN } & -3.337 & $-6.654^{* *}$ \\
& $(4.106)$ & $(3.179)$ \\
NSW & $0.805^{* * *}$ & $0.841^{* * *}$ \\
& $(0.219)$ & $(0.222)$ \\
$F D$ & 0.243 & 0.217 \\
& $(0.357)$ & $(0.364)$ \\
RD & 6.621 & 7.221 \\
FOCUS & $(0.005)$ & $(7.981)$ \\
& -0.012 & -0.013 \\
IND & $(0.013)$ & $(0.014)$ \\
YEAR & yes & yes \\
Constant term & yes & yes \\
Observations & $-9.294^{* *}$ & $-9.720^{* *}$ \\
Wald & $(4.593)$ & $(4.581)$ \\
$R^{2}$ & 925 & 925 \\
\hline
\end{tabular}

Note: The value of $\mathrm{t}$ is in brackets and all regression controls the annual and industrial variables.

Note: $* * *, * *$ and $*$ are marked at the significance level of $1 \%, 5 \%$, and $10 \%$, respectively.

Column 1 in Table 6 shows that the coefficient of banking financial connection is negative but not statistically significant. Column 2 suggests that the coefficient of the non-bank financial connection is significantly negative at the $5 \%$ level. Such an outcome indicates that the non-bank financial connections of private enterprises are not conducive to enterprise operation and development.

\subsection{Robustness Test}

To ensure the stability of the research results, robustness tests were conducted for the different measures of operation performance. Existing research shows that financial connections can improve enterprise debt; hence, financially associated enterprises can maximise the higher ratio of leveraged corporate profits. Such a situation makes it possible for the interest cost of debts and the repayment pressure to lead to the financial connection lowering the performance of the enterprise. Based on this finding, this research excludes liabilities, considers only the equity of shareholders $(R O E)$ and examines whether financial connection still exerts a negative effect on business performance of enterprises. The regression results are shown in Table 7. 
Table 7. Results of the Robustness Tests.

\begin{tabular}{llllll}
\hline \multirow{2}{*}{ Variables } & ROE & & & & \\
\cline { 2 - 6 } & Model 1 & Model 2 & Model 3 & Model 4 & Model 5 \\
\hline \multirow{2}{*}{ FIN } & $-8.545^{* *}$ & $-8.632^{* *}$ & $-8.656^{* *}$ & $-8.678^{* *}$ & $-8.677^{* * *}$ \\
& $(3.868)$ & $(3.839)$ & $(3.856)$ & $(3.866)$ & $(3.893)$ \\
NSW & & $1.637^{* * *}$ & $1.643^{* * *}$ & $1.646^{* * *}$ & $1.659^{* * *}$ \\
& & $(0.351)$ & $(0.351)$ & $(0.352)$ & $(0.352)$ \\
$F D$ & & 0.219 & 0.118 & 0.102 \\
& & $(0.589)$ & $(0.591)$ & $(0.588)$ \\
$R D$ & & & 8.798 & 7.069 \\
FOCUS & & & $(13.52)$ & $(13.45)$ \\
IND & & & -0.023 \\
YEAR & & & & $(0.021)$ \\
Constant term & YES & & YES & YES \\
Observations & YES & YES & YES & YES & YES \\
Wald & $\left(3.189^{* * *}\right.$ & $-23.57^{* * *}$ & $-24.04 * * *$ & $-25.23 * * *$ & $-24.99^{* * *}$ \\
$R^{2}$ & 935 & $(7.311)$ & $(7.373)$ & $(7.362)$ & $(7.375)$ \\
\hline
\end{tabular}

Note: The value of $\mathrm{t}$ is in brackets and all regression controls the annual and industrial variables.

Note: $* * *, * *$ and $*$ are marked at the significance level of $1 \%, 5 \%$, and $10 \%$, respectively.

As shown in Table 7, the coefficient of FIN is significantly negative under the $5 \%$ significance level, denoting that using other indicators to measure the performance of the enterprise does not change the empirical conclusion and that the model results are stable. Moreover, the results in Table 7 also prove that the absolute value of the core variable FIN coefficient increased by approximately two times. The negative effect of the financial connection on the business performance of the enterprise is more obvious, thus implying that relative to its effect on the return on assets, the adverse impacts of financial connection on the return on equity is more serious.

\section{Conclusions and Suggestions}

\subsection{Conclusions}

The phenomenon of financial connection has been existing widely in the listed private enterprises in this period of economic transition in China. Existing research mainly focused on the influence on mergers and acquisitions and funding in morass. However, such subjects are uncommon in the daily operations of enterprises, but nevertheless this research put attention to the relationship between degree of financial connection and enterprise operating performance which is the main concern of investors under the function of multiple factors such as capital structure, the level of financial development and so on. Relevant data from listed private enterprises in China from 2014 to 2018 were used as the sample for this research. Then, a panel data random effects model was employed to construct a regression model in order to examine the relationship between enterprise operating performance and degree of financial connection.

The results can draw conclusions as follows. First, financial connections cannot effectively improve the operating performance of an enterprise and even exerts a negative effect to a certain extent. The cost of establishing and maintaining a financial affiliate offsets the advantages of management.
Second, compared with large-scale enterprises, smaller private enterprises are more negatively affected by financial connections. Third, in areas with low financial development, financial connections have a significant negative impact on the business performance of enterprises, which is significantly higher than the impact on those firms in regions of higher financial development. Finally, the negative effect of non-bank financial connections on the performance of enterprises is more obvious than that of banking financial connections.

\subsection{Recommendations}

Based on the above conclusions, several recommendations are proposed.

First, the company management should consider the characteristics and situation of the firm in weighing the advantages and disadvantages of the financial industry related to the enterprise. More importantly, to maintain and build this relationship, the managers must lobby and engage in rent-seeking activities to establish a link between financial connections. However, in the current anti-corruption political climate, such endeavours entail great risk, and the finance-related benefits may fail to meet the requirements of the risk premium. Additionally, rent-seeking behaviour can have a substantial impact on corporate image. Therefore, enterprises should apply their limited resources to certain activities, such as production and operation, which are conducive to their long-term development, thereby improving their operating performance.

Second, market regulators should be guided by the finding that enterprises seeking to establish and maintain financial related behaviours cannot translate such behaviours into business performance benefits. That is, corporate rent-seeking behaviour is a waste of the society's resources, which can otherwise be used in productive activities, and is not conducive to the long-term development of society. Therefore, 
more regulations should be implemented to reduce the incidence of financial ties. At the same time, during this economic transition in China, private enterprises face larger fluctuations and uncertainty. Therefore, corresponding policy measures should be introduced and support for private enterprises increased to solve the financing constraints of private enterprises. Such measures would make it easier for private enterprises to obtain the resources needed for production, thus achieving long-term stable development.

Third, market investors should be cautious in choosing investment objects. Under the current state of the economic transformation in China, financial connections are bound to be susceptible to restrictions and control due to its rapidly reforming financial systems and increasingly strict financial regulations. Hence, such connections of affordable means do not exist for long. Moreover, enterprises with such connections and those that are seeking to establish such links tend to use resources for rent-seeking activities that can be used for normal production. This behaviour is damaging to their own long-term development, so investors should be considered in forging such associations.

\section{Funding Support}

We appreciate the financial support of National Social Science Foundation of China (17CJY060).

\section{References}

[1] Cull R., L. X. C. Xu. (2005). Institutions, Ownership and Finance: The Determinants of Profit Reinvestment among Chinese Firms. Journal of Financial Economics. 77(1): 117-146.

[2] Jovanovic B. (1982). Selection and the Evolution of Industry. Econometrica. 50(3): 649-670.

[3] Fung M. K. (2014). R\&D, knowledge spillovers and stock volatility. Accounting \& Finance. 46(1): 107-124.

[4] Francis B. B., I. Hasan. and X. Sun. (2009). Political connections and the process of going public: Evidence from China. Journal of International Money and Finance. 28(4): 696-719.

[5] Dhawan R. (2001). Firm size and productivity differential: theory and evidence from a panel of US firms. Journal of Economic Behavior \& Organization. 44(3): 269-293.
[6] Rajan G. R., L. Zingales. (1998). Financial Dependence and Growth. The American Economic Review. 88(3): 559-586.

[7] Salim M., R. Yadav. (2012). Capital Structure and Firm Performance: Evidence from Malaysian Listed Companies. Procedia - Social and Behavioral Sciences. 65(3): 156-166.

[8] Vu M. C., T. T. Phan, N. T. Le. (2018). Relationship between board ownership structure and firm financial performance in transitional economy: The case of Vietnam. Research in International Business and Finance. 45: 512-528.

[9] Jiang K., S. Wang. (2009). Firms in Economic Distress: Survival Strategies and Economic Factors. Ssrn Electronic Journal.

[10] Blau B. M., T. J. Brough and D. W. Thomas et al. (2013). Corporate lobbying, political connections, and the bailout of banks. Journal of Banking \& Finance. 37(8): 3007-3017.

[11] Huang Q., F. Jiang. E. Lie. et al. (2014). The role of investment banker directors in M\&A. Journal of Financial Economics. 112 (2): 269-286.

[12] Chan C. C., B. H. Lin., Y. H. Chang et al. (2013). Does bank relationship matter for corporate risk-taking? Evidence from listed firms in Taiwan. North American Journal of Economics and Finance. 26: 323-338.

[13] Luo W., Y. Zhang., N. Zhu. (2011). Bank ownership and executive perquisites: New evidence from an emerging market. Journal of Corporate Finance. 17(2): 352-370.

[14] Higgins H. N. (2013). Conflicts of interest between banks and firms: Evidence from Japanese mergers. Pacific-Basin Finance Journal.

[15] Güner B., U. Malmendier, G. Tate. (2008). Financial expertise of directors. Journal of Financial Economics 88(2), 323-354.

[16] Kang, M. J. and Kim, A. (2017), Bankers on the Board and CEO Incentives. Eur Financial Management 23(2). 292-324.

[17] Houston J. F., L. L. Jiang., C. Lin et al. (2014). Political connections and the cost of bank loans. Journal of Accounting Research. 52(1): 193-243.

[18] Leonard K. 2015. Political capital and moral hazard. Journal of Financial Economics. 116(1): 144-159.

[19] Cebeci U., B. Sezerel. (2008). Performance evaluation model for R\&D department: An integrated balanced scorecard and analytical hierarchy process approach. 2008 3rd international conference on intelligent system and knowledge engineering. 1276-1281. 